\title{
ENFRENTAMENTO DO CYBERBULLYING NAS ESCOLAS INSPIRADO NOS PRINCÍPIOS E METODOLOGIAS da Pedagogia Social
}

\author{
COVERING CYBERBULLYING IN SCHOOLS INSPIRED BY THE \\ PRINCIPLES AND METHODOLOGIES OF SOCIAL PEDAGOGY
}

\begin{abstract}
Neide Aparecida Ribeiro
Doutora em Educação pela Universidade Católica de Brasília. Professora da Universidade Estadual do Tocantins e da Faculdade de Palmas. Tocantins - TO - Brasil ORCID: https://orcid.org/0000-0002-2715-8743 neidearibeiro@gmail.com

Geraldo Caliman

Pós-Doutorado em Educação pela Università Pontificia Salesiana de Roma. Professor da Universidade Católica de Brasília. Brasília - DF- Brasil ORCID: https://orcid.org/0000-0003-2051-9646 ger.caliman@gmail.com
\end{abstract}

Resumo: $\mathrm{O}$ artigo visa compreender as dimensóes da violência virtual no fenômeno do cyberbullying, tema de tese concluída do Doutorado em Educação no programa de pós-graduação da Universidade Católica de Brasília. Entre os problemas pesquisados, verificou-se o papel do professor na lida diária com estudantes que sofrem e/ou praticam a violência virtual nas escolas de Palmas/TO, em mensagens ofensivas de textos, vídeos e áudios e o descumprimento da Lei n. 13.185/2015, em vigor no Brasil desde junho de 2016. O interacionismo simbólico e o funcionalismo foram os modelos teóricos utilizados, nas perspectivas de autores como Becker (2008), na obra Outsiders, e Goffman (2013), em Estigma, para a análise dos dados gerados. A metodologia foi lastreada na pesquisa qualitativa, o que permitiu a flexibilização das técnicas de entrada em campo com aplicação de entrevistas, observação indireta e análise documental. Os documentos da pesquisa foram submetidos à Plataforma Brasil, em 07/04/2017, tendo sido emitido Certificado para Apresentação de Apreciaçáo Ética (CAAE) nº. 69064317.0.0000.0029, aprovado em 17 de julho de 2017 pelo Comitê de Ética (CE) da UCB, parecer nº. 2.175.797. Os resultados preliminares apontaram que as escolas náo têm conhecimento dos programas legais de combate à intimidaçáo sistemática efetuada por meio de violências virtuais. Por outro lado, percebeu-se a importância de um professor engajado em sala de aula, comprometido com o ensino-aprendizagem, mas, sobretudo, envolvido na construção de uma cultura de paz, no uso de metodologias e princípios inspirados pela Pedagogia Social.

Palavras-chave: Cyberbullying. Pedagogia Social. Violência Virtual. 
Aвstract: The article aims to understand the dimensions of virtual violence in the phenomenon of cyberbullying, a thesis topic completed by the Doctorate in Education in the postgraduate program of the Catholic University of Brasilia. Among the problems researched, the role of the teacher in the daily deal with students who suffered and / or practiced virtual violence in Palmas / TO schools, offensive messages of texts, videos and audios, and noncompliance with Law no. 13.185 / 2015, in force in Brazil since June 2016 (BRAZIL, 2015). The symbolic interactionism and functionalism was the theoretical model used in the perspectives of the authors as Becker (2008), in the work "Outsiders" and Goffman (2013), in "Stigma", for the analysis of the data generated. The methodology was based on qualitative research, which allowed the flexibility of the entry techniques such as the application of interviews, indirect observation and documentary analysis (DEMO, 2011). The research documents were submitted to Plataforma Brasil, on 04/17/2017, and a Certificate for Presentation of Ethical Appreciation (CAAE) was issued. 69064317.0.0000.0029, approved on July 17, 2017 by the UCB Ethics Committee (CE), opinion no. 2,175,797. Preliminary results indicate that schools are not aware of legal programs to combat systematic bullying through virtual violence. On the other hand, it was perceived the importance of a teacher engaged in the classroom, committed to teaching-learning, but above all involved in building a culture of peace, through the use of methodologies and principles inspired by Social Pedagogy.

Keywords: Cyberbullying. Social Pedagogy. Virtual Violence.

\section{Introduçáo}

$\mathrm{O}$ artigo estuda as dimensóes da violência virtual no fenômeno do cyberbullying, tema de pesquisa do doutorado em Educação no Programa de Pós-Graduação da Universidade Católica de Brasília. O principal problema versou sobre o papel do professor na lida com estudantes que sofrem e/ou praticam a violência virtual nas escolas de Palmas/TO, questão que tem previsão na Lei n. 13.185/2015, vigente no Brasil desde junho de 2016, e que prevê, entre outros objetivos, a capacitação de docentes e equipes pedagógicas para a implementação das ações de discussão, prevenção, orientação e solução do bullying e cyberbullying. (BRASIL, 2015)

$\mathrm{O}$ aporte teórico foi baseado no interacionismo simbólico e no funcionalismo de Becker (2008), na obra Outsiders, e Goffman (2013), em Estigma, utilizados na análise dos dados gerados. Quanto à metodologia optou-se pela modalidade qualitativa nas aplicaçóes das técnicas de entrevistas, observação indireta e análise documental e, como método auxiliar, fez-se uso da pesquisa exploratória para a compreensão do fenômeno docy- 


\section{berbullying. (HERNÁNDEZ SAMPIERI; FERNÁNDEZ COLLADO;} BAPTISTA LUCIO, 2013; DEMO, 2011)

Os resultados preliminares indicam que os profissionais das escolas visitadas estão despreparados para enfrentar situaçôes que envolvem estudantes vítimas e/ou agressores de violências virtuais. Do lado da escola, gestores, supervisores pedagógicos e professores, por vezes bem-intencionados, não possuem a formação necessária para lidar com problemas geralmente desconhecidos do universo virtual. A proibiçáo do uso de tecnologias que conectam os estudantes à internet prevista nos regimentos escolares e projetos pedagógicos é uma solução ineficaz.

A compreensão da linguagem e o interesse da conexão virtual dos jovens e adolescentes é uma necessidade que se faz presente no universo escolar. Cabe, então, repensar como a internet pode ser utilizada em uma nova dimensão do processo de ensino e aprendizagem quando as práticas educacionais são inspiradas na pedagogia social.

\section{Entendendo o fenômeno do cyberbullying}

Antes da explicação sobre o cyberbullying, faz-se necessário apresentar o significado de bullying, um termo que advém do inglês bully e que significa valentão, usado para expressar um tipo de violência, embora não seja comum a tradução para o português.

Foi Dan Olweus, um pesquisador sueco pioneiro nos estudos do fenômeno, que tratou em profundidade do conceito de bullying na obra Bullying at School: What we know and what we can do, publicada na década de 1970. Para Olweus (1993), o bullying é uma forma de violência física pela qual o agressor ou um grupo de agressores expóe uma pessoa a açóes negativas repetidas e continuadas. O bullying é classificado por esse autor em duas formas: a direta, em que o agressor ataca a vítima mediante violência física e verbal, e a indireta, com o isolamento social e proposital da vítima de um grupo.

Foi a partir dos estudos de Olweus que o bullying tomou a dimensão e o interesses de outros pesquisadores, como Berntsson e Vallejo (2015, p. 174), que explicaram que o bullying "representa aquelas açóes e palavras que têm por objetivo ridicularizar ou fazer mal a alguém.” (tradução nos- 
sa) Diferencia-se do cyberbullying porque enquanto no bullying a agressão é presencial, no cyberbullying o agressor faz uso de um meio eletrônico, utilizando-se das tecnologias de informação e comunicação (TIC's). Tratase, portanto de "um conjunto de comportamentos e atitudes agressivas que ocorre por meio da TIC's, podendo ser perpetrado por um grupo ou por um indivíduo contra outros grupos ou indivíduos". (WENDT; WEBER, 2014, p. 42). No bullying, a assimetria de poder é aparente na ausência das habilidades da vítima para se defender das açôes agressivas às quais fica exposta, enquanto no cyberbullying o anonimato aumenta o poder do agressor (LIMA, 2011; BLAYA, 2013). Todavia, no cyberbullying, assim como no bullying, as açôes violentas dos agressores ocorrem entre os pares na forma de maus-tratos verbais, mediante a prática de xingamentos, ironias, insultos, deboche ou ameaças e acusaçóes injustas. (LISBOA; HORTA E ALMEIDA, 2014)

Seixas, Fernandes e Morais (2016) criticam a presença mais comum dos três elementos presentes no bullying e no cyberbullying, como apontados por outros autores: intencionalidade, repetição e desequilíbrio do poder, ao mencionarem que na Internet nem sempre se pode afirmar que as agressóes ocorrem entre os pares porque podem ser realizadas por pessoas anônimas. Dessa forma, esses autores definem o cyberbullying como "o uso indevido das tecnologias digitais para, deliberada e repetidamente, agir de forma hostil com o intuito de causar dano a outro(s)." (SEIXAS; FERNANDES; MORAIS, 2016, p. 36). Shariff (2011) contraria o ponto de vista desses autores ao afirmar que o cyberbullying ocorre entre os pares porque essas pessoas usuárias da internet ingressam em grupos virtuais que possuem afinidades com os interesses de seus membros. Para o autor, não existe assimetria de poder entre o agressor e a vítima segundo o critério de interesses idênticos ou assemelhados.

Em pesquisas realizadas com 360 estudantes na Suécia, Slonje e Smith (2008) relatam os diferentes tipos de cyberbullying e as variaçóes de percepção dos participantes a respeito do fenômeno, se comparados ao bullying tradicional. Nesse estudo, constataram que os estudantes se sentiram muito mais intimidados com videoclipes publicados na internet. Os autores afirmam que o conceito de bullying foi ampliado incluindose a agressão indireta praticada por terceiros na propagação de histórias inverídicas; agressão social e/ou exclusão social; agressão relacional para 
danificar as relaçóes entre os pares, como a autoestima e/ou status social. Por seu turno, no cyberbullying a agressão "[...] ocorre através de dispositivos tecnológicos modernos, e especificamente telefones celulares ou a internet." (SLONJE; SMITH, 2008, p. 147)

Olweus (2012, p. 521), constata que no bullying "um aluno é provocado repetidamente de maneira cruel e prejudicial. Mas não chamamos de bullying quando a provocação é feita de maneira amigável e brincalhona." $\mathrm{O}$ autor destaca que as pesquisas se equivocam ao investigarem o fenômeno do cyberbullying isolado do bullying. $\mathrm{O}$ recorte das pesquisas de Olweus serve de alerta para que o pesquisador seja cauteloso em achados de dados encontrados na pesquisa de campo ao asseverar que o cyberbullying apresenta um formato diferenciado do bullying praticado na Internet, dado que o sofrimento psicológico é acentuado quando a vítima apenas sofre de açóes provenientes do cyberbullying.

Um dos problemas encontrados na presente pesquisa refere-se à tênue distância entre a agressão e a brincadeira em que o consentimento do outro é essencial. A situação é visível no bullying em que o agressor, pela compleição física, pelo tom da voz, pela postura corporal nas açóes impostas, sistemáticas e contínuas, causam danos à vítima face à sua posiçáo de vulnerabilidade. A diferença entre a brincadeira e o bullying por ser de difícil configuração e passa, por vezes, imperceptível aos professores e aos responsáveis pelos cuidados com os estudantes. Isso se explica pela linguagem e gestos praticados pelos jovens externada por um vocabulário próprio, onde quer que se encontrem. No cyberbullying, essa distinção ainda é mais complexa pela linguagem utilizada pelos jovens e adolescentes nas redes sociais. Porém, a partir do momento que esse comportamento passa para uma atitude autoritária e hostil capaz de serem insuportáveis pelos colegas, perfaz-se o cyberbullying. (ARAÚJO, 2017)

Feitas as consideraçóes sobre bullying e cyberbullying, verifica-se que existem várias definiçốes de cyberbullying e em moldes variados, a depender do autor. No intuito de esclarecer as modalidades de cyberbullying, sem a intençáo de exauri-las, opta-se pelos ensinamentos dos formatos do fenômeno de Blaya (2013); Lima (2011); Seixas, Fernandes, Morais (2016); Shariff (2009), quais sejam: a) mensagens inflamadas ou provocaçóes incendiárias (flaming); b) assédio; c) perseguição virtual; d) vídeo-linchamento; e) exposição de informaçôes da vida privada da vítima; f) difama- 
ção; g) exclusão ou bloqueio não autorizado de membro em grupos on line; h) perturbação virtual, dentre outros.

Em resumo: Tanto o bullying quanto o cyberbullying, exigem comportamentos agressivos, sistemáticos e intencionais para causar mal a alguém e em situação de desigualdade entre os envolvidos. No cyberbullying, entretanto, verifica-se que: a) os comportamentos agressivos são assíncronos e indiretos; b) a desigualdade de poder decorre da habilidade técnica e do anonimato do agressor na rede; c) ausência de indicadores verbais explícitos face à prática diferenciada da linguagem; d) exige perícia tecnológica; e) é uma violência de difícil contenção devido ao contexto de infinitude das publicaçôes e replicaçóes das postagens na rede; f) apresenta uma complexidade e variedade de comportamentos dos observadores como passivos ou ativos nas mensagens em replicaçôes, likes (curtidas favoráveis), comentários favoráveis e desfavoráveis; g) descontrole dos observadores; e, por fim, h) caráter permanente das agressóes. (SEIXAS; FERNANDES; MORAIS, 2016)

\section{Metodologia de pesquisa utilizada nas escolas de Palmas/Tocantins}

A metodologia utilizada para a investigaçáo do fenômeno do $c y$ berbullying nas escolas de Palmas/TO, de abordagem qualitativa, consistiu na compreensão do fenômeno investigado na perspectiva subjetiva que os participantes têm da realidade (HERNÁNDEZ SAMPIERI; FERNÁNDEZ COLLADO; BAPTISTA LUCIO, 2013; DEMO, 2011). Para tanto, os instrumentos que serviram como meios de coleta e/ou geraçáo de dados na pesquisa foram: observaçáo indireta, análise documental e entrevistas semiestruturadas envolvendo 45 (quarenta e cinco) participantes, entre estudantes, professores, supervisores pedagógicos e gestores das escolas.

As entrevistas aplicadas, com perguntas abertas, possibilitaram aos participantes emitir opinióes sobre os questionamentos formulados, entre eles: elucidaçáo do uso da internet das e nas escolas; identificaçáo de casos de cyberbullying entre os pares e, por fim, explicaçóes sobre como resolveram os conflitos existentes entre os estudantes nas redes sociais. 


\section{Resultados preliminares: as razóes que levam os adolescentes e jovens a postarem mensagens nas redes sociais}

Entre os resultados preliminares encontrados na pesquisa, verificouse que a necessidade dos estudantes de se comunicarem com outros jovens, de dialogarem sobre assuntos variados, de mostrarem ao mundo o que fazem, quem eles são e do que são capazes de fazer foram algumas das razóes que os leva a postarem mensagens em redes sociais.

Para os jovens, quem possui um smarphone tem melhores condiçôes de conseguir contatos e novos amigos, ou seja, constitui-se como fonte de amizades e possíveis laços de afeto. $\mathrm{O}$ aparelho celular carregado na palma da máo ou nos bolsos dos uniformes dos estudantes nas escolas representa mais que um adereço ou objeto de uso pessoal: é considerado pelos estudantes um meio imediato de dialogar com o mundo mediante o ingresso nas redes sociais. Utilizada como ambiente de popularização de encenação do 'Eu', a internet permite a criação de perfis pessoais públicos e privados. Os jovens relatam suas preferências de lazer (filmes, jogos, esportes) e têm a liberdade de brincar com as informaçóes disponíveis. São práticas recorrentes dos estudantes: as trocas e comentários de notícias, e as fotografias, textos e áudios no universo das relaçóes sociais mantidas nos grupos on line. (BLAYA, 2013; SANTAELLA, 2007)

Os estudantes das escolas, entretanto, nos primeiros momentos das entrevistas, se colocaram em uma posição defensiva ao afirmarem que não portavam e/ou usavam o celular no ambiente escolar. Respostas dadas pela metade, medo da divulgação de seus nomes e/ou informaçóes sobre possíveis descumprimentos das regras da escola ou recebimento de sançóes foram percebidas pela pesquisadora em várias entrevistas. Temos como exemplo o relato da estudante ED1, ao dizer que náo usava o celular na escola no início da entrevista, "Não. Porque o meu celular quebrou.... posso... mas prefiro não usar." Porém, à medida que os estudantes se sentiam mais à vontade com a pesquisa, relataram que usam a internet na escola. ED1 afirmou que usava as redes sociais na escola onde estuda, no horário do recreio: "Quando tinha celular usava praticamente todas as redes sociais na escola. Facebook (pausa) Usava (pausa), era o Whats... Face... Instagram, Snap... essas coisas." Ao falar sobre seus amigos, disse ter apenas cinco, mas ao se referir 
sobre os amigos das redes sociais informou ter "três mil, duzentos e poucos. Mas que converso mesmo, são novecentos e poucos [...]"

Portanto, a primeira razão encontrada entre os participantes da pesquisa foi a necessidade de estarem em grupo, de terem amigos. Esse número surpreendente de relações em redes sociais é justificado pelos laços de amizade de vários níveis e a rápida capacidade de interação social/ virtual. Nas palavras de Blaya (2013, p. 26), "a internet pode, pois, ser um meio de trocas, de partilhas (músicas, vídeos, informaçôes), de encontros e de relaçôes e até mesmo de amizade." A rede social funciona como uma praça virtual e possui várias funcionalidades, entre elas a de propiciar que mensagens possam ser trocadas nos grupos com vários membros simultaneamente, a exemplo do WhatsApp, e, ao mesmo tempo, o usuário ter condiçốes de conversar no contato privado do grupo.

A segunda razão que leva os jovens e adolescentes a ficarem plugados na internet, conforme a pesquisa, foi a autoafirmação pessoal. A estudante EA7 esclarece o motivo pelo qual as pessoas postam mensagens nas redes sociais ao afirmar que: "eu acho que... (pausa), as pessoas postam coisas assim, ou porque já sofreram bullying ou se acham demais pra poder afetar outra pessoa." (Sic!). Ao ser perguntada sobre o que significa "acham demais", a estudante complementou: "tipo... é igual... é vou procurar uma forma de falar melhor... é só tipo... há, eu sou a tal... a mais bonita... tal aí fica... e acha que é melhor que os outros." (EA7)

As respostas direcionam para a compreensão de que a rede social tem uma funcionalidade de diário pessoal e apresenta-se como lugar de autoafirmação da própria identidade. Nas palavras de Giddens (2002, p. 54), a auto-identidade

Não é um traço distintivo, ou mesmo uma pluralidade de traços, possuído pelo indivíduo. É o eu compreendido reflexivamente pela pessoa em termos de sua biografia. A identidade ainda supóe a continuidade no tempo e no espaço: mas a auto-identidade é essa continuidade reflexivamente interpretada pelo agente. Isso inclui o componente cognitivo da pessoidade [personhood]. Ser uma "pessoa" não é apenas ser um ator reflexivo, mas ter o conceito de uma pessoa (enquanto aplicável ao eu e aos outros). 
A identificação do próprio Eu e o que os outros pensam do Eu pode ser explicada na escolha pelos jovens da melhor rede social para navegar. A identificação de si mesmos, nas palavras dos estudantes nas entrevistas, tem relaçâo direta com a popularidade que eles podem ganhar na escola e a facilidade de acesso das redes sociais do Instagram e do Facebook. A preferência dessas modalidades de redes sociais é evidenciada na visibilidade, acessibilidade e velocidade do fluxo das informaçóes, elementos valorizados pelos jovens e adolescentes. Para que as mensagens tenham essas características, seus conteúdos devem ser curtos, as imagens vivas, anímicas, cômicas. A avaliação de que uma postagem foi aceita pelos usuários está diretamente relacionada com o número de curtidas e comentários. Se o resultado é inverso, ou seja, ausência de likes (curtidas), os jovens entrevistados afirmaram que se sentem isolados e excluem a mensagem da rede social.

A autoafirmação como uma das razôes de uso das redes sociais pelos jovens estudantes pode ser comprovada nas mensagens postadas na internet, diretamente relacionada à descrição das viagens, dos novos amigos e amigas, no falar de si mesmos (das preferências de roupas, restaurantes; objetos e animais que curtem; viagens que fazem; demonstraçáo dos amigos que têm...), enfim, da rotina que levam.

Essa liberdade de se mostrarem nas redes é vista no encontro dos usuários, nos grupos on line. Sem hora marcada e tendo o controle de seu próprio tempo e dos conteúdos a serem postados, seus membros afiliam-se às comunidades a que se sentem pertencidos. Seja para postarem mensagens indevidas ou para relatarem casos de abusos ou de sofrimento, as motivaçôes das postagens são multivariadas e complexas. A empatia pelo outro, a necessidade de mostrarem um físico perfeito e as ideias que têm, aliados às reaçóes que têm ao se sentirem pressionados pelas exigências sociais, ou a serem muitas vezes o que não são em essência, implicam postagens de mensagens que os colocam em situaçóes de risco na rede.

Essas questóes se explicam pelo fato de que na praça virtual, a internet, internautas adultos, jovens e adolescentes podem ver os outros e a si mesmos. Ao conversarem com os usuários dessa praça, sentam-se nos bancos virtuais (links, arquivos, grupos, comunidades), observam as mensagens, comentam, divertem-se. Mas, sobretudo, a visibilidade de si mesmos fica evidenciada nas poses do próprio corpo, na personalização das 
imagens, na exposição dos dados pessoais, ao mostrarem ao mundo o que querem que seja visto.

A terceira razão, que vários entrevistados mencionaram, diz respeito às diversôes virtuais que se caracterizam nas brincadeiras de replicar vídeos, fotos e áudios cômicos. Os memes foram citados como as principais postagens dos estudantes por fazerem parte da sociabilidade virtual. As risadas, as curtidas, os emojis aparecem nessa linguagem virtual das redes sociais ao enviarem, receberem, replicarem e divulgarem os memes. O termo foi criado por Richard Dawkins em 1989, na obra O gene egoísta, utilizado pelo autor para descrever a memória como "unidade de informação que se multiplica de cérebro em cérebro ou entre locais onde a informação é armazenada." (ADAMI, 2018) Na internet, o termo é utilizado para demonstrar a propagação de uma imagem, contendo ou não alteraçôes de fotografias, desenhos ou vídeos que se tornam virais. Vários estudantes relataram a postagem dos memes: "[...] eu? eu gosto de postar tipo... coisas que tão pegando muita fama na rede social...(pausa) e... vídeos engraçados [...]" (EA7) Essas modalidades de imagens remodeladas são anímicas, metafórmicas, transformadas pelos usuários para se tornarem divertidas. Sáo informaçóes que para Bauman (2005) têm cunho interativo, embora volátil e fluido. Os memes têm a função de fazer rir, mesmo que seja de uma imagem não autorizada e remodelada a partir da tecnologia da internet.

Além dos memes, a internet em si mesma, para vários estudantes entrevistados, serve para brincar em jogos e outros aplicativos que estão disponíveis gratuitamente para serem baixados (download) pelo usuário. Brincadeiras realizadas na internet e originárias da internet são questôes novas e difíceis de serem controladas pelos gestores e professores das escolas porque, para os estudantes, não passam de uma brincadeira, mesmo que alguns deles tenham a consciência de que essa conduta pode levar a consequências danosas para as vítimas. E é essa uma das principais preocupações relatadas por diretores, orientadores e professores das escolas.

Percebe-se que apesar da proibição expressa nos projetos pedagógicos e regimentos internos das escolas visitadas, mediante imposição de regras e restriçóes ao uso da wifi da unidade escolar ou da internet privada dos estudantes, são controles que não impedem as práticas maliciosas das redes sociais. São normas aplicadas nas escolas, após a anuência dos 
pais e responsáveis pelos discentes em reuniōes pedagógicas, que preferem acreditar na eficácia de regras proibitivas ao invés de dialogarem sobre os riscos e perigos da internet com seus filhos. Trata-se, portanto, de regras inócuas pela facilidade de serem violadas e, por outro lado, difíceis de serem inspecionadas pelos funcionários da escola nos aparelhos celulares dos estudantes.

A quarta razão evidenciada nos achados da pesquisa está relacionada à transgressão na internet. Por ser um ambiente aberto, livre e multifacetado, os professores entrevistados reconheceram as dificuldades e limitaçóes de se controlar. A proibição de acessar a internet da unidade escolar para uso pessoal dos estudantes é uma regra impositiva encontrada nos documentos analisados e corroborada pelas respostas dos funcionários dessas escolas. Entretanto, os estudantes sáo orientados a utilizar a internet particular no celular apenas nas atividades supervisionadas pelos professores, conduta que nem sempre é cumprida porque descobrem a senha da escola, fato relatado por EC9: "[...] mas, aí às vezes, ela não quer a gente tenha a senha (risos), e aí a gente acaba usando a internet da escola mesmo [...]” É o que Goffman (2013) elenca como o medo da pessoa de se tornar estigmatizada, de quebrar regras nas instituiçôes onde está vinculada.

Por outro lado, alguns estudantes exemplificaram transgressôes virtuais capazes de ofender outras pessoas:

[...] Uai, hoje em dia é assim, ne? Elas fazem brincadeiras umas com as outras. Achando que todo mundo gosta dessa brincadeira, posta para fazer a galera rir... no whatsapp mesmo. A outra pessoa não deve gostar ne? Depois acontece assassinato, muitas brigas entre as pessoas por causa do racismo. (EC3)

Mais adiante, o entrevistado relata sua atuação na internet:

Eu posto piadinha Deep (pausa) não sei se a senhora já ouviu falar na DeepWeb? Lá você pode fazer tudo que quiser nele... vender...tipo comprar cocaína... qualquer coisa lá... tipo tudo de ruim... aí eu faço um desenho aqui meio tremular... tipo, um ventilador tremendo, quase quebrando, aí eu falo ó... esse você compra um ventilador do tipo web...aí eu gosto de postar 
essas coisas [...]. Eu não entro porque precisa do TOR, e o TOR é lento, mas é fácil de entrar...eu recomendo você não entrar porque eles raqueiam seus dados....aí eu uso wifi do colégio que é mais difícil de rastrear. (EC3)

A estudante EC4 abordou as consequências de postagens de fotografias na rede que acarretaram em conflitos entre os estudantes da escola:

[...] eu já vi muito (pausa), é... como posso dizer?(pausa) Tipo uma pessoa postou uma foto e tal... aí a outra foi lá e já colocou apelidinhos e tal, e trouxe muita briga já... tem gente que fala mal, não tem? Aí não gostou e aí quer expressar o que não gostou, vai lá e coloca. [..] aqui na escola mesmo, já teve briga por causa disso. [...] realmente, têm pessoas que já é pra atingir alguém, sabem realmente, o porquê eu não sei, porque não tem motivos, pra uma pessoa simplesmente ir lá e depravar a outra $[\ldots]$

O conflito gerado a partir de postagens maldosas na internet foi uma das razóes elencadas pelos funcionários das escolas para a proibiçáo do uso do celular na escola:

[...] não, não é permitido, aliás, ele pode utilizar mediante ordem do professor. [...] justamente para não haver...tipo, né? Fica brincando, eles vão ao banheiro, fica fazendo imagens inadequadas, né? (inaudível) [...] as meninas maiores de idade têm o costume de ficar tirando fotos, né, inadequadas [...] (FC6)

E pela gestora de uma das escolas pesquisadas, ao justificar que o celular somente pode ser utilizado como recurso pedagógico, para evitar brigas entre os alunos:

[...] brigas, filmam, vai pras redes sociais. É...talvez quando o professor vai chamar a atençáo de um aluno, já teve também eles gravarem, gravarem à parte, talvez o professor teja um pouco mais exaltado, alterado, né? De colegas, fazendo aqueles 
fakes, já fizeram fake da página da escola também... isso é o que a gente consegue ter acesso e ver porque a dimensão é muito grande. A gente tá sempre procurando acompanha-los da maneira que pode [...] (FB1)

São condutas praticadas na internet que se assemelham àquelas realizadas no ambiente físico das unidades escolares: falar mal do professor, rabiscar as paredes e as portas dos banheiros das escolas com palavrôes ou desenhos são transgressôes comuns vivenciados pelos estudantes. São condutas definidas por Becker (2008) como desviantes porque são assim interpretadas pela sociedade ou no ambiente onde ocorrem. Para Shariff (2011), todavia, o que mudou na internet foi o modo de operacionalizar as condutas, em que muitas vezes o transgressor pode ou não ser identificado, o que dificulta a investigação e a punição severa previstas e aplicadas nas escolas.

\section{Professores inspirados na Pedagogia Social}

Os funcionários da escola, em especial os professores, para conseguirem identificar, mediar e atender às demandas conflituosas que envolvem os estudantes na internet devem absorver as qualificaçóes de um mestre com uma formação humanística e diferenciada. Ribeiro e Caliman (2015, p. 13) explicam que o professor que conhece a pedagogia social tem condições de se adaptar às condiçôes inusitadas do conflito. Ele tende a atuar com

Uma pedagogia social de portas abertas e congruente com complexas e mutantes realidades sociais compromete-se a modificar realidades e a enfrentar desafios da vida cotidiana da pessoa e implica no envolvimento de diversos atores pedagógicos e sociais para desenvolver e garantir a extensão e diversificação das circunstâncias favorecedoras da aprendizagem. Entre os atores qualificantes dos processos socioeducativos está a figura do Educador Social. (RIBEIRO; CALIMAN, 2015, p. 92) 
O educador social, no Brasil, ainda não tem a valorização que deveria, face à educação tradicional e conservadora imposta nas escolas públicas. Ao contrário de países como a Alemanha, em que os educadores sociais são capacitados para lidarem com pessoas em situação de vulnerabilidade, a educação no Brasil é carente nessa seara e tem campo para a inserção desses profissionais (SILVA; SOUZA NETO; MOURA, 2011). Entretanto, o art. $5^{\circ}$. da Lei ${ }^{\circ}$. 13.185/2015, em vigor no Brasil desde 2016, estabelece medidas de "conscientização, prevençáo, diagnose e combate à violência e à intimidação sistemática (bullying)" e dispóe sobre a obrigação das escolas de elaborar e publicar relatórios bimestrais de ocorrências de bullying e cyberbullying na esfera federal, estadual e municipal para o planejamento de açôes futuras (BRASIL, 2015). Essa legislação é o ponto de partida e uma obrigação a ser cumprida pelos profissionais das escolas públicas, no sentido de buscarem metodologias adequadas e capazes de lidar com a violência virtual.

Essa preocupação legal é justificada porque os estudantes que ficam plugados diuturnamente nas redes sociais e expóem informaçóes pessoais e da própria família se colocam em risco porque muitas vezes não são orientados a lidar com e na internet. Em respostas às entrevistas, vários estudantes informaram que sofrem e/ou praticam bullying e cyberbullying e, por essa razáo, se automutilam. Perguntados se os pais ou professores sabiam que se autolesionavam, caíram aos prantos ao relatarem que essas pessoas não iriam compreendê-los e seria perda de tempo eles terem conhecimento sobre tais questôes.

Por outro lado, as proibições estipuladas nos documentos encontrados na pesquisa das quatro escolas visitadas, um deles inclusive prevendo sançóes aos estudantes assemelhadas às criminais, somente pioram o ambiente escolar porque as ações por parte dos estudantes são desconhecidas dos funcionários das escolas. São problemas que dependem de profissionais da educação com uma formação humanizadora, que saibam diagnosticar os jovens e adolescentes em situaçáo de sofrimento, que tenham um mínimo de conhecimento das redes sociais utilizadas nas escolas e, sobretudo, inspirem confiança aos estudantes para que possam dialogar sobre as questóes que lhes afligem.

Caliman (2015, p. 9) explica que o educador social é 
a figura que representa o elo das relaçôes, promove relaçôes e está presente seja física que simbolicamente em meio aos educandos. A pedagogia da presença náo representa uma vigilância mas um caminhar com o educando de modo que ele invista com um voto de confiança na proposta educativa. Na construção das relaçóes reveste-se de grande importância o investimento no espirito de família em torno do ambiente educativo.

Portanto, o professor gabaritado com as qualificaçóes da pedagogia social tem uma escuta afinada e comprometida na lida com o outro, baseada no respeito aos seus valores e aos conhecimentos adquiridos, sem qualquer forma de discriminação (FREIRE, 1996). É o que explica a vocação de professores pautados nos princípios da pedagogia social ficarem marcados nas recordaçóes dos estudantes por serem "acolhedores, sensitivos e vocacionados para a docência dadas as habilidades que se somam ao exemplo de vida que demonstraram aos estudantes no decorrer da aprendizagem.” (RIBEIRO, 2017, p. 137)

Em situaçôes de conflitos envolvendo os estudantes na internet é imprescindível que o professor, bem como os funcionários da escola, entre eles supervisores pedagógicos, orientadores educacionais e diretores, tenham conhecimento do que seja o cyberbullying, sejam pacientes na diagnose do sofrimento que o envolve e estejam inspirados nos princípios da pedagogia social.

\section{Consideraçóes finais}

Neste artigo tematizamos a aplicação dos princípios e metodologias inspiradas na pedagogia social em casos de violências virtuais envolvendo estudantes de escolas públicas do nível fundamental de Palmas/TO.

Os resultados preliminares revelaram que as razóes que levam os estudantes a navegar na internet, ingressar em grupos on line e postar mensagens de texto, áudios e vídeos são diversas, entre elas a de encontrarem no terreno virtual um campo para praticarem açóes tidas como normais, mas que para os professores são típicas de transgressôes assemelhadas às realizadas presencialmente. As brincadeiras que vários estudantes fazem, 
mesmo aquelas de mau gosto, são perpetradas nas redes sociais, e ao mesmo tempo são encaradas como diversão para os membros dos grupos e sofrimento para quem tem seus dados e/ou imagens expostas.

Compreender os níveis de ações perpetradas na internet requer profissionais da educação cautelosos em suas ações e conhecedores de postulados mínimos em tecnologia. Mas, sobretudo e principalmente, pautados na humanização das didáticas e abordagens dialógicas inspiradas no respeito, na habilidade das diagnoses e mediaçóes em violências virtuais como o cyberbullying.

\section{Referências}

ADAMI, Ana. Memes. Disponível em: <https://www.infoescola.com/comunicacao/ memes/>. Acesso em: 7 nov. 2018.

ARAÚJO, Sônia Maria dos Santos. Cyberbullying: palavra e imagens que trazem sofrimento. Palmas: Nagô Editora, 2017.

BAUMAN, Zygmunt. Vidas desperdiçadas. Trad. Carlos Alberto Medeiros. Rio de Janeiro: Zahar, 2005.

BECKER, Howard Saul. Outsiders: estudos de sociologia do desvio. Tradução Maria Luiza X. de Borges; revisão técnica Karina Kuschnir. Rio de Janeiro: Jorge Zahar, 2008.

BERNTSSON, Elías; VALLEJO, Sabrina. Cómo superar el bullying y sus secuelas em 2 etapas transformadoras. (Ebook). Publicado por AumenandoMiAutestima.com. 2015.

BLAYA, Catherine. Violências e maus-tratos em meio escolar. Lisboa, Portugal: Instituto Piaget, 2006.

BRASIL. Lei $n^{\circ}$. 13.185 de 6 de novembro de 2015. Institui o Programa de Combate à Intimidação Sistemática (Bullying). Disponível em: <http://www.planalto.gov.br/ ccivil_03/_Ato2015-2018/2015/Lei/L13185.htm>. Acesso em: 10 set. 2018.

CALIMAN, G. Pedagogia social, relaçóes humanas e educação. In: MAFRA, J. F.; BATISTA, J.C.F.; BAPTISTA, A.M.H. Educação básica: concepções e práticas. São Paulo: BT Acadêmica. 2015. p. 187-203.

DAWKINS, Richard. O gene egoista. Tradução Rubino Rejane. São Paulo: Companhia das Letras, 1989.

DEMO, Pedro. Metodologia do conhecimento científico. São Paulo: Atlas, 2011. 
FREIRE, Paulo. Pedagogia da autonomia: saberes necessários à prática educativa. 17. ed. Sáo Paulo: Paz e Terra, 1996.

GIDDENS, Anthony. Modernidade e identidade. Tradução, Plínio Dentzien. Rio de Janeiro: Jorge Zahar, 2002.

GOFFMAN, Irving. Estigma: notas sobre a manipulação da identidade deteriorada. Tradução de Márcia Bandeira de Mello Leite Nunes. 4. ed. Rio de Janeiro: LTC, 2013.

HERNÁNDEZ SAMPIERI, R.; FERNÁNDEZ COLLADO, C.; BAPTISTA LUCIO, P. Metodologia de pesquisa. 5. ed. Porto Alegre: Penso, 2013.

LIMA, Ana Maria de Albuquerque. Cyberbullying e outros riscos na internet: despertando a atenção de pais e professores. Rio de Janeiro: Walk Editora, 2011.

LISBOA, Carolina Saraiva de Macedo e al. Mitos e fatos sobre o Bullying. (in) LISBOA, Carolina Saraiva de Macedo; WENDT, Guilherme Welter; PUREZA, Juliana da Rosa. Mitos e fatos sobre o bullying: orientaçôes para pais e profissionais. Novo Hamburgo: Sinopsys, 2014, p. 15-27.

OLWEUS, Dans. Bullying at scholl. What we know and what we can do. London: Blackwell, 1993.

OLWEUS, Dans. Cyberbullying: Na overrated phenomenon? In: European Journal of Developmental Psychology. v. 9, Issue 5. pp. 20-568, 2012. Disponível em: <https:// www.researchgate.net/profile/Dan_Olweus/publication/254222937_Cyberbullying_ An_overrated_phenomenon/links/58527d8508aef7d030a4e9dc.pdf >. Acesso em: 20 set. 2018.

PIERONI, Vittorio; FERMINO, Antonia; CALIMAN, Geraldo. Pedagogia da alteridade: para viajar a Cosmópolis. Brasília: Liber Livro, 2014.

RIBEIRO, N. Aparecida; CALIMAN, Geraldo. Reabilitação criminal: o papel da educação social em processos de violência e exclusão. Revista Interacções, vol. 11, n. 38, 2015. Pp. 80-101.

RIBEIRO, Neide Aparecida. Formação de professores: o enfrentamento do cyberbullying nas escolas do Distrito Federal. Anais do II INTERFOR, VII ENFORSUP. Palmas, Tocantins, Brasil, 12 a 15 de setembro de 2017, UFT. Disponível em: <https://docs.uft.edu.br/share/proxy/alfresconoauth/api/internal/shared/ node/3iMMPL_wRISw597jz_UEw/content/Anais\%20(II\%20Interfor\%20e\%20 VII\%20Enforsup\%202017).pdf>. Acesso em: 7 set. 2018.

SANTAELLA, Lúcia. Linguagens líquidas na era da mobilidade. São Paulo: Paulus, 2007.

SCOCUGLIA, Afonso Celso, et al. Pedagogia social. (org). 2 . ed. revisada. São Paulo: Expressão e Arte Editora, 2011. 
SEIXAS, Sónia; FERNANDES, Luís; DE MORAIS, Tito. CYBERBULLYING: um guia para pais e educadores. Lisboa, Portugal: Plátano Editora, 2016.

SHARIFF, Shahenn. Cyberbullying: questôes e soluçóes para a escola, a sala de aula e a família. Tradução: Joice Elias Costa; revisão técnica: Cleo Fante. Porto Alegre: ArtMed, 2011.

SILVA, R. et al. Áreas prioritárias para atuação da pedagogia social no Brasil. 3. ed. In R. Silva et al. (org.). Pedagogia Social. São Paulo: Expressão \& Arte Editora, 2011.

SLONJE, Robert; SMITH K. Peter. Cyberbullying: Another main type of bullying? Personality and Social Sciences. Scandinavian Journal of Psychology, 2008, 49, pp. 147-154. Disponível em: <https://www.ncbi.nlm.nih.gov/pubmed/18352984>. Acesso em: 20 set. 2018.

WENDT, Guilherme Welter; WEBER, João Luís Almeida. Discutindo agressão e vitimização eletrônica. Mitos e fatos sobre o bullying: orientaçóes para pais e professores. Org. por Carolina Saraiva de Macedo Lisboa, Guilherme Weldt e Juliana da Rosa Pureza. Novo Hamburgo: Sinopsys, 2014.

Recebido em 5 fev. 2019 / Aprovado em 20 mar. 2019

Para referenciar este texto:

RIBEIRO, N. A.; CALIMAN, G. Enfrentamento do cyberbullying nas escolas inspirado nos princípios e metodologias da Pedagogia Social. EccoS - Revista Cientifica, São Paulo, n. 48, p. II5-I32. jan./mar. 2019. Disponível em: <https://doi. org/I0.5585/EccoS.n48.II $577>$. 